\title{
OPTIMIZATION OF TECHNICAL TRAINING OF ICE-HOCKEY PLAYERS AGED 8-17 YEARS
}

\author{
Gracijus Girdauskas, Rimas Kazakevičius \\ Lithuanian Sports University, Kaunas, Lithuania
}

\begin{abstract}
Research background and hypothesis. Training models in athlete training have already been determined by sport researchers (Hellard et al., 2006. The programme that has been developed and tested by one alternative experiment is targeted to optimize the purposeful technical training for 8-17-year-old ice hockey players.

Research aim was to determine technical training models.

Research methods. A long-term experiment of one alternative was carried out involving subjects from 8 to 18 years in 2000-2010. The programmes for technical training were developed with regard to the time ratio, measures taken and recommendations of foreign experts. Later the programmes have been adjusted to the results obtained. The following tests have been used for evaluation of the skating technique: to evaluate specific skills - forward and backward skating; to evaluate the puck control - manoeuvre skating driving the puck and without the puck.

Research results. Analysis of the results in the initial training period shows that the greatest improvement in the results has been registered in manoeuvre skating driving the puck $-11.6 \%$, and in backward skating - about $8 \%$. A significant improvement in the results of the basic training period has been observed in backward skating $-7 \%$ as well as in $30 \mathrm{~m}$ standing skating $-6.3 \%$. In the special training period a more marked increase in the results has been registered in backward skating $-5.2 \%$ as well as in $30 \mathrm{~m}$ standing skating $-3.8 \%$.

Discussion and conclusions. This is due to the lack of special skills and a complex biomechanical structure of the performance of the technical action. Sport performance was influenced by adolescent developmental patterns, and the optimal adjustment of the programme, taking into account the initial and basic training period analysis.

Results of the present research allow us to conclude that 1) Athletes' training programmes, taking into account the recommendations, were effective. 2) The greatest improvement in the results was registered within the $1^{\text {st }}$ and $2^{\text {nd }}$ stages of athletes' training. We believe that this is due to a complex biomechanical structure of the performance of the technical action. After the improvement, the growth of the results slows down. 3) Time ratio for technical training is distributed in the following way: 1 st stage $-55-53 \%$, 2nd stage $-50-48 \%$ and 3 rd stage $-47-44 \%$.
\end{abstract}

Keywords: technical training, manoeuvre skating, experimental programme, optimization of training, training model.

\section{INTRODUCTION}

$\mathrm{A}$ thletes' training is a multi-stage process (Weineck, 2004; Платонов, 2004). Athlete's success is mainly determined by genetically-induced potential physical, spiritual, mental and intellectual capacities (Malina et al., 2005) as well as by genetically determined adaptations in response to the applicable training programme (Wolfarth et al., 2005).
No less focused and effective training of young athletes is conditioned by coach's ability to use up-to-date, scientifically based sports training technologies (Skurvydas, 2002; Lyle, 2006; Reilly, 2007). This is especially important for small countries with extremely limited number of talented athletes.

Although the conception about athletes' longterm training periods is often quite different (Kent, 
1998), almost all authors distinguish between the initial, deepened, specialised and final periods in the selection of athletes as well as the initial, basic, special sports performance achievement periods (Платонов, 2004). The period encompassing childhood, adolescence and young adult stages is characterized by a favourable reputation for personal development, which leads to growth and development trends (Malina, 1988; Malina et al., 2005). For this reason it is relevant to find gifted and talented children for sports in order to achieve their sports performance goals (Martens, 2004). Otherwise, the most receptive for individual capacity to develop age stages might be lost (Naul et al., 1998). That is why scientifically-based optimal training programmes adequate to the regularities of growth and maturation of young athletes are of great importance, and in particular, those training programmes which are adequate to their individual body functional powers and specific skills (Bar-Or, 2005).

No scientific publications have been found to support optimal technical training models in particular periods of the long-term training of icehockey players that would lead to optimal technical fitness models.

Research hypothesis suggests the programme that has been developed and is targeted to optimize the purposeful technical training of ice hockey players aged 8-17 years. Research object was technical training and fitness models and their interaction of ice-hockey players aged 8-17 years.

Research aim was to determine technical training models as well as technical fitness model characteristics of ice-hockey players aged 8-17 years.

\section{RESEARCH METHODS}

The programmes have been designed taking into account recommendations of sport researchers from the Czech Republic, Russia and Sweden (Букатин, Колузганов, 1986; Быстров, 2000; Gustavson et al., 2002).

- A long-term experiment was carried out in 2000-2010. The subjects of the experiment were young athletes aged 8-17 years (training programmes are appended, Tables 1-3).

- Method of theoretical analysis and generalization.

- Testing.

- Mathematical statistics (arithmetic mean, the deviation of the average values of the significance of differences by Student's t-assessment criteria $(n=17)$.

- Comparative analysis. Dynamics of research results was assessed by P. Siris methodology.

Table 1. Sample of micro-cycle weekly plan in the initial training period of the preparatory stage

\begin{tabular}{|c|c|c|}
\hline Days of the week and content & Purposefulness & Volume and duration, min \\
\hline $\begin{array}{l}\text { Monday } \\
\text { - Preparatory skating technique improvement drills } \\
\text { - Improvement of manoeuvre skating } \\
\text { - Playing with tasks }\end{array}$ & $\begin{array}{l}\text { Aerobic } \\
\text { Anaerobic alactic } \\
\text { Mixed }\end{array}$ & $\begin{array}{l}20 \\
30 \\
20\end{array}$ \\
\hline $\begin{array}{l}\text { Tuesday } \\
\text { - Preparatory drills of the puck control } \\
\text { - Improvement of passing and receiving the puck } \\
\text { - Improvement of wrist shot } \\
\text { - Playing with tasks }\end{array}$ & $\begin{array}{l}\text { Aerobic } \\
\text { Anaerobic alactic } \\
\text { Aerobic } \\
\text { Mixed }\end{array}$ & $\begin{array}{l}20 \\
30 \\
20 \\
20\end{array}$ \\
\hline Wednesday & Rest day & \\
\hline $\begin{array}{l}\text { Thursday } \\
\text { - } \quad \text { Preparatory drills of skating technique improvement } \\
\text { - Improvement of backward skating technique } \\
\text { - Improvement of ability to change direction skating } \\
\text { - } \quad \text { Playing with tasks }\end{array}$ & $\begin{array}{c}\text { Aerobic } \\
\text { Aerobic } \\
\text { Aerobic } \\
\text { Mixed }\end{array}$ & $\begin{array}{l}20 \\
30 \\
20 \\
20\end{array}$ \\
\hline $\begin{array}{l}\text { Friday } \\
\text { - } \quad \text { Preparatory drills of the puck control technique } \\
\text { - Improvement of deceptive motions } \\
\text { - Improvement of the puck shooting } \\
\text { - } \quad \text { Playing with tasks }\end{array}$ & $\begin{array}{l}\text { Aerobic } \\
\text { Anaerobic alactic } \\
\text { Aerobic } \\
\text { Mixed }\end{array}$ & $\begin{array}{l}20 \\
30 \\
20 \\
20\end{array}$ \\
\hline $\begin{array}{l}\text { Saturday } \\
\text { Competition in technique actions, relay, agility games }\end{array}$ & Mixed & 60 \\
\hline
\end{tabular}


Table 2. Sample of micro-cycle weekly plan in the basic training period of the preparatory stage

\begin{tabular}{|c|c|c|}
\hline Days of the week and content & Purposefulness & Volume and duration, min \\
\hline $\begin{array}{l}\text { Monday } \\
\text { - Preparatory drills to improve skating technique } \\
\text { - Improving skating technique in different playing positions } \\
\text { - Improving skating technique in transition from one mode to another } \\
\text { - } \quad \text { Playing with tasks }\end{array}$ & $\begin{array}{c}\text { Aerobic } \\
\text { Anaerobic alactic } \\
\text { Mixed } \\
\text { Mixed }\end{array}$ & $\begin{array}{l}20 \\
30 \\
20 \\
20\end{array}$ \\
\hline $\begin{array}{l}\text { Tuesday } \\
\text { - Preparatory drills of the puck control } \\
\text { - Improving driving the puck technique } \\
\text { - Improving } 1 \times 1 \text { technique } \\
\text { - Training game }\end{array}$ & $\begin{array}{c}\text { Aerobic } \\
\text { Anaerobic alactic } \\
\text { Aerobic } \\
\text { Mixed }\end{array}$ & $\begin{array}{l}20 \\
20 \\
20 \\
30\end{array}$ \\
\hline Wednesday Rest day & & \\
\hline $\begin{array}{l}\text { Thursday } \\
\text { - Preparatory drills to improve skating technique } \\
\text { - Improving manoeuver skating backwards } \\
\text { - Improving manoeuver skating backwards of players in different } \\
\text { playing positions } \\
\text { - Training game with tasks }\end{array}$ & $\begin{array}{l}\text { Aerobic } \\
\text { Aerobic } \\
\text { Anaerobic alactic } \\
\text { Mixed }\end{array}$ & $\begin{array}{l}20 \\
20 \\
20 \\
30\end{array}$ \\
\hline $\begin{array}{l}\text { Friday } \\
\text { - Preparatory drills of the puck control } \\
\text { - Improving deceptive motions and throwing the puck technique } \\
\text { - Improving throwing the puck technique of offensive and defensive } \\
\text { players } \\
\text { - Training game with tasks }\end{array}$ & $\begin{array}{c}\text { Aerobic } \\
\text { Anaerobic alactic } \\
\text { Mixed } \\
\text { Mixed }\end{array}$ & $\begin{array}{l}20 \\
20 \\
20 \\
30\end{array}$ \\
\hline $\begin{array}{l}\text { Saturday } \\
\text { Integrated training }\end{array}$ & Match & 90 \\
\hline
\end{tabular}

Table 3. Sample of micro-cycle weekly plan in the special training period of the preparatory stage

\begin{tabular}{|c|c|c|}
\hline Days of the week and content & Purposefulness & Volume and duration, min \\
\hline $\begin{array}{l}\text { Monday } \\
\text { - Special preparatory drills to improve skating technique } \\
\text { - Improving various techniques in different positions } \\
\text { - Improving various skating techniques moving from one skating } \\
\text { technique to another } \\
\text { - Training game }\end{array}$ & $\begin{array}{l}\text { Aerobic } \\
\text { Anaerobic alactic } \\
\text { Mixed } \\
\text { Mixed }\end{array}$ & $\begin{array}{l}20 \\
20 \\
20 \\
30\end{array}$ \\
\hline $\begin{array}{l}\text { Tuesday } \\
\text { - Drills for improving the puck control } \\
\text { - Improving } 1 \times 1 \text { technique } \\
\text { - Technique improvement by using playing drills } \\
\text { - Training game with tasks }\end{array}$ & $\begin{array}{l}\text { Aerobic } \\
\text { Anaerobic alactic } \\
\text { Mixed } \\
\text { Mixed }\end{array}$ & $\begin{array}{l}20 \\
20 \\
20 \\
30\end{array}$ \\
\hline $\begin{array}{l}\text { Wednesday } \\
\text { Improving individual technique }\end{array}$ & $\begin{array}{l}\text { Day for recovery } \\
\text { Aerobic }\end{array}$ & 50 \\
\hline $\begin{array}{l}\text { Thursday } \\
\text { - Preparatory drills to improve skating and the puck control } \\
\text { - Playing drills } 2 \times 1 ; 3 \times 1 ; 3 \times 2 \\
\text { - Training game with tasks }\end{array}$ & $\begin{array}{l}\text { Aerobic } \\
\text { Anaerobic alactic } \\
\text { Mixed }\end{array}$ & $\begin{array}{l}20 \\
30 \\
40 \\
\end{array}$ \\
\hline $\begin{array}{l}\text { Friday } \\
\text { - Preparatory playing drills to improve skating and the puck control } \\
\text { - Improving technique tactics actions in defence zone } \\
\text { - Improving technique tactics of completing the attack } \\
\text { - Training game with tasks }\end{array}$ & $\begin{array}{l}\text { Aerobic } \\
\text { Aerobic alactic } \\
\text { Aerobic } \\
\text { Mixed }\end{array}$ & $\begin{array}{l}20 \\
20 \\
20 \\
30\end{array}$ \\
\hline $\begin{array}{l}\text { Saturday } \\
\text { Integrated training }\end{array}$ & Match & 90 \\
\hline
\end{tabular}


Research organization. Changes in the results of the main technical actions performance after the experimental programmes were under investigation. The results were determined by "New Test".

1. Manoeuver skating was estimated according to the test recommended by A. Bukatin, V. Koluzganov (1986): standing behind the goal line after the signal subjects had to overcome obstacles moving in a "Snake-like" manner. The obstacles were located in certain places (Figure 1).

2. Manoeuver skating driving the puck was estimated using the same test.
3. $20 \mathrm{~m}$ standing skating and $20 \mathrm{~m}$ standing backward skating.

4. $30 \mathrm{~m}$ standing skating.

The table shows that there was a different time ratio for improving skating and driving the puck techniques at different training stages. In the opinion of Russian specialists (Букатин, Колузганов, 1986; Быстров, 2000), 40\% of the total practice time should be given to technical training techniques while Swedish professionals allow $50 \%$ of the total practice time for technical training techniques (Gustavson, 2002).

Figure 1. Test to assess the skating technique of ice hockey players (manoeuver skating) (Букатин, Колузганов, 1986)

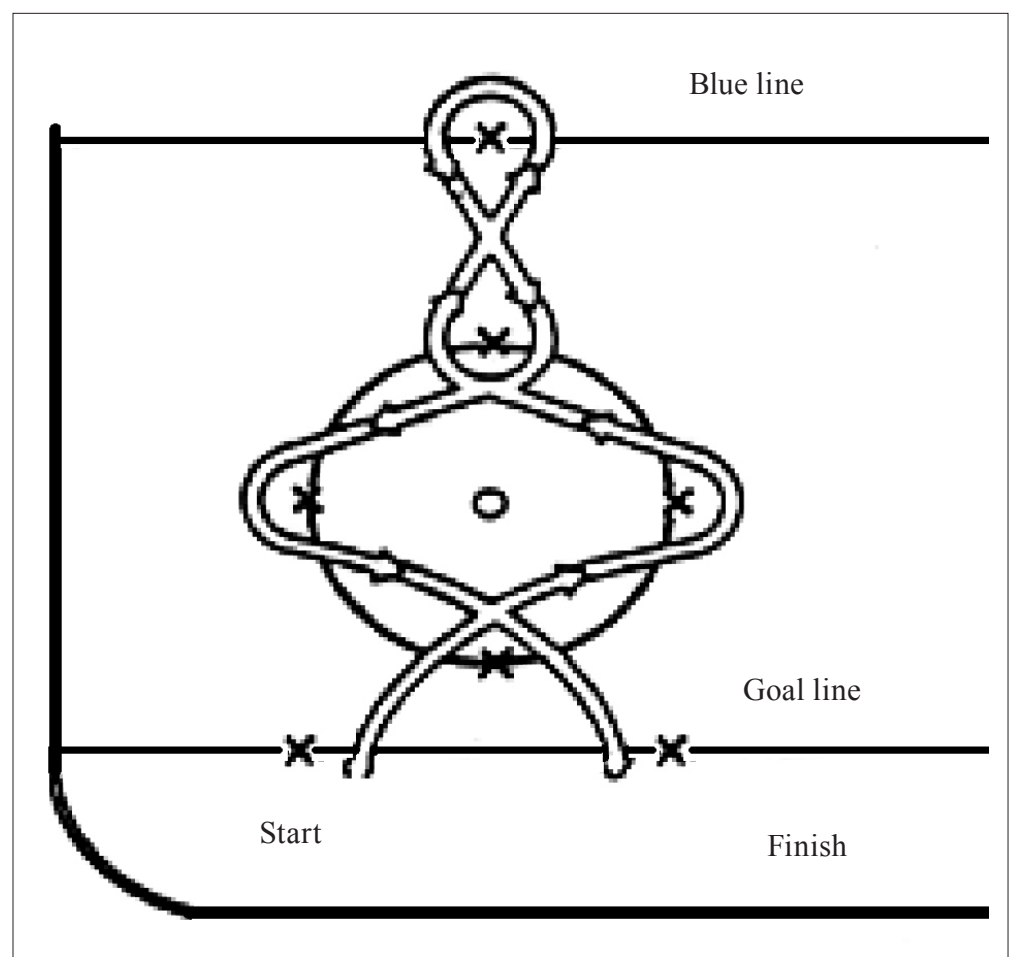

Table 4. Time ratio (\%) for skating technique and driving the puck technique at various periods of training

\begin{tabular}{|c|c|c|c|c|c|c|c|c|c|c|}
\hline \multirow{2}{*}{$\begin{array}{l}\text { Means of training } \\
\text { Skating technique }\end{array}$} & \multicolumn{3}{|c|}{$\begin{array}{l}\text { Initial training period } \\
\quad(8-10 \text { years })\end{array}$} & \multicolumn{3}{|c|}{$\begin{array}{l}\text { Basic training period } \\
\quad(11-13 \text { years })\end{array}$} & \multicolumn{4}{|c|}{$\begin{array}{l}\text { Special training period } \\
\text { (14-17 years) }\end{array}$} \\
\hline & 43 & 40 & 33 & 26 & 24 & 22 & 17 & 15 & 13 & 10 \\
\hline $\begin{array}{l}\text { Driving the puck } \\
\text { technique }\end{array}$ & 11 & 15 & 20 & 24 & 25 & 26 & 30 & 31 & 32 & 34 \\
\hline Total, \% & 54 & 55 & 53 & 50 & 49 & 48 & 47 & 46 & 45 & 44 \\
\hline
\end{tabular}




\section{RESEARCH RESULTS}

Initial training period. The greatest changes have been registered in manoeuver skating test driving the puck within the $2 \mathrm{nd}$ and $3 \mathrm{rd}$ years of training $-11.6 \%$ while improvement of results within the 1st and 2nd years of training was $9.6 \%$. In $20 \mathrm{~m}$ standing skating and $20 \mathrm{~m}$ standing backward skating test a more worked improvement was registered in $20 \mathrm{~m}$ standing backward skating: within the 1st and 2 nd as well as within the 2 nd and 3 rd years of training $-8.0 \%$. The comparison of the results in the 2 nd and 3rd years of training has revealed a lower increase of results $-5.5 \%$.

Basic training period (11-13 years). During the research period change in results of technical training was not uniform. There was a marked increase in the improvement of manoeuvre skating test results within the 2 nd and 3 rd years of training $-9 \%$, and within the 1 st and 2 nd $-8.4 \%$. The greatest improvement in the results of skating driving the puck has been registered within the 2 nd and 3rd years of training $-8.8 \%$, and within the $1 \mathrm{st}$ and 2 nd years of training $-7.2 \%$.

Special training period (14-17 years). The results of the research best describe a purposeful training of athletes. During the whole period of the research results of technical fitness were not uniform. The most worked improvement has been observed in performing tests of manoeuvre skating and skating driving the puck. The most marked improvement was registered in the results of manoeuvre skating within the 3rd and the 4th years of training $-7.9 \%$. A lower increase in the results of manoeuvre skating test was observed within the 1st and 2nd years of training $-3.5 \%$ and within the 2 nd and 3 rd year of training $-1.7 \%$.The greatest increase in the results of skating driving the puck was registered within the $3 \mathrm{rd}$ and the 4 th years of training $-6.0 \%$. However, a lower increase in the results was registered between the 1st and 2 nd years of training $-3.3 \%$, within the 2 nd and 3 rd years of training $-1.2 \%$.

An increase in the results has been registered in $20 \mathrm{~m}$ backward skating and $30 \mathrm{~m}$ standing skating. The most marked improvement was registered in the results of backward skating within the 1 st and 2 nd years of training $-5.2 \%$. A lower increase was observed within the 2nd and the 3 rd years of training $-3.5 \%$, and within the $3 \mathrm{rd}$ and 4 th years of training $-3.1 \%$. The greatest increase was registered in the test of $30 \mathrm{~m}$ skating from a standing start within the 1st and 2 nd years of training $-3.8 \%$. A lower increase in the results was observed within the $2 \mathrm{nd}$ and the 3 rd years of training $-2.4 \%$; and within the $3 \mathrm{rd}$ and 4 th years of training $-1.8 \%$.

\section{DISCUSSION}

Goal-directed training of athletes is best described by the results of the research (Figures 3 and 4). During the whole period of the research results of technical fitness were divergent. The most worked improvement has been observed in performing tests of manoeuvre skating and skating driving the puck

In the period of initial training manoeuvre skating performance improvement resulted in the absence of specific skills and the applied training methods. Subsequently, the results of performance decreased due to too few numbers of hours given for skating technique training.

A marked improvement in the results of the puck control can be explained by the fact that this technique is quite complicated, and because of the absence of specific skills, a reasonable number of hours were given for mastering the skill. Improvement in other tests, i. e. 20 skating forward and backward, can be explained by a complex biomechanical structure of technical actions and the successfully selected training methods. The comparison of the results of the athletes under investigation with the analogous research results of Russian and Swedish scientists has revealed the results of our testing to be higher, but the difference was not statistically significant $(\mathrm{p}>0.05)$.

In the basic training period time ratio distribution was determined by the training specifics of technical game, recommendations of foreign researchers and programme adjustment for educational monitoring. Significant increase in results was also affected by regularities in adolescent development patterns and correctly selected teaching methodology. It can be seen that higher performance results have been observed in the technical actions with a complex biomechanical structure. Relatively more time has been allocated for them in the training programme. Change of results in athletes' training confirms the correctness of the training methodology. Comparison of testing results of our athletes with the above-mentioned test results obtained by Russian and Swedish researchers allows us to assert that our testing results were higher, but the difference was not statistically significant $(\mathrm{p}>0.05)$. 
Figure 2. Changes in results of manoeuvre skating and skating driving the puck for icehockey players aged 8-17

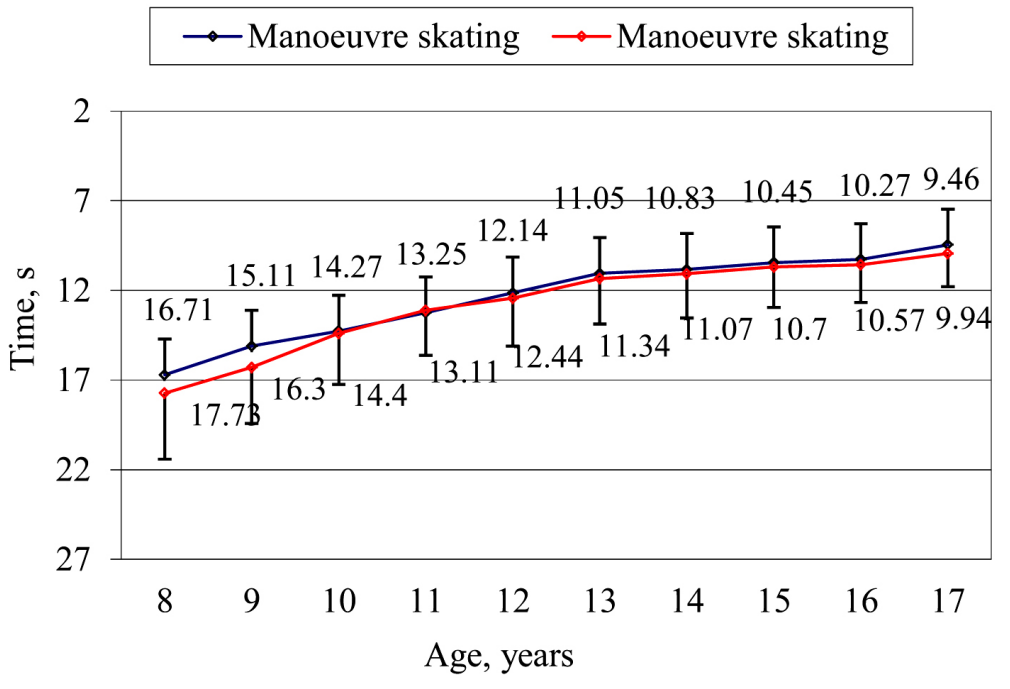

Figure 3. Changes in results of various skating tests for ice-hockey players aged 8-17 years

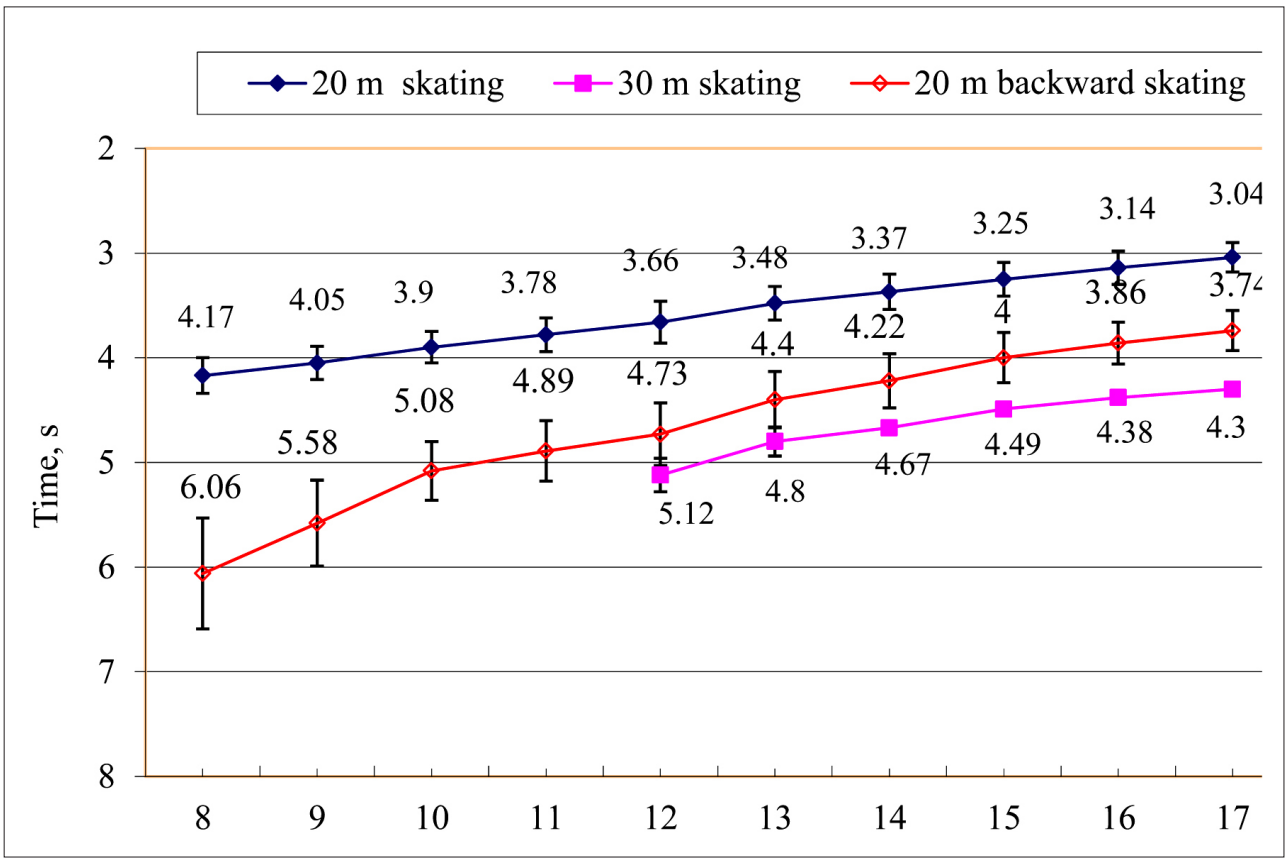

Special training period. When planning weekly micro-cycles (Monday, Wednesday, Friday), application of technical exercises during the match was emphasized. The ratio of specific measures was increased up to $80 \%$. The amount of technical actions and effectiveness during matches was recorded. The analysis of the results was adjusted to individual players' technical development plans: 2-3 morning training sessions were added to weekly micro-cycles. Correctness of the purposeful athlete training is best characterised by the achieved results.

Comparing the results obtained with the testing results of the Russian and Swedish researchers in similar studies it has been found that differences in research results were not statistically reliable $(p>0.05)$. We believe that difference in increase and regularity of results in manoeuvre skating without the puck and driving the puck is due to a more complex coordination and biomechanical structure of technical actions. It can also be asserted that improvement of the results was influenced by individual (additional) tasks.

Development and adjustment of the program, based on the recommendations of foreign scientists, helped us to determine the optimal time ratio and the main technical tools to improve technical actions in various stages of development. 


\section{CONCLUSIONS AND PERSPECTIVES}

1. Sports training technologies are of utmost importance for the final results: selection efficiency, the up-to-date scientific knowledge, methods, tools and innovations used as well as integrity and consistency in all stages of fitness training, a targeted development planning and adjustment taking into account athletes' fitness indices, determination of the ratio for teaching and training measures and the adjustment of the results achieved.

2. Study of ice hockey technical fitness at different training periods has shown that experimental programmes were effective (changes in the results are presented in Figures 3 and 4). A marked increase in the improvement of test results in the initial training period has been observed in manoeuvre skating driving the puck $-11.6 \%$ as well as in backward skating $-8.0 \%$.
In the basic training period, the greatest improvement in the results has been registered in backward skating $-7.0 \%$ and $30 \mathrm{~m}$ standing skating $-6.3 \%$.

In the specialised training period the maximum difference in the results has been registered in performing the backward skating test $-5.2 \%$ and $30 \mathrm{~m}$ standing skating test $-3.8 \%$. This was determined by the lack of special skills and a more complex biomechanical structure of technical action performance. Sport performance was influenced by adolescent developmental patterns and adjustment of individual programmes in the initial and basic training stages.

3. Model of time ratio distribution of skating and puck control techniques:

- in the initial training period - 54, 55 and $53 \%$ respectively (Figure 2 );

- in the basic training period - 50, 49, $48 \%$ respectively;

- in the special training period $-47,46,45$ and $44 \%$ respectively.

\section{REFERENCES}

Bangsbo, J. (1994). Fitness training in Football - a Scientific Approach. Copenhagen: August Krogh Institute University of Copenhagen.

Bar-Or, O. (2005). The Child and Adolescent Athlete. Blackwell Publishing: IOC.

Faigenbaum, A., Westcott, W. (2000). Strength and Power for Young Athletes. Human Kinetics.

Gustavsson, A. Olsson, T., Nordstrom, P. (2003). Rapid loss of bone mineral density of the femoral neck after cessation of ice hockey training: A 6-year longitudinal study in males. Journal of Bone and Mineral Research, 18 (11), 1964-1969.

Hellard, P., Avalos, M., Lacoste, L. et al. (2006). Assessing the limitations of the Banister model in monitoring training. Journal of Sports Sciences, 24 (5), 509-520.

Kent, M. (1998). The Oxford Dictionary of Sport Science and Medicine. Oxford University Press.

Lyle, J. (2006). Sports Coaching Concepts: A framework for Coaching Behaviour. London: Routledge.

Malina, R. R., Bouchard, C., Bar-Or, O. (2005). Growth, Maturation, and Physical Activity. Human Kinetics.
Malina, R. R. (1988). Young Athletes: Biological, Psychological, and Educational Perspectives. Human Kinetics.

Martens, R. (2004). Successful Coaching. Human Kinetics. Naul, R., Hardman, K., Pieron, M., Skirstad, B. (1998). Physical Activity and Active Lifestyle of Children and Youth. Schorndorf: Hofmann.

Reilly, T. (2007). The Science of Training - Soccer. London: Routledge.

Skurvydas, A. (2002). Sportininku rengimo abėcèlè. Ugdymas. Küno kultūra. Sportas, 1 (42), 52-57.

Weineck, J. (2004). Optimal Ttraining. Balingen Spitta Verlag.

Wolfarth, B., Bray, M. S., Hagberg, J. M. et al.(2005). The human gene map for performance and healthrelated fitness phenotypes: the 2004 update. Medicine and Science in Sports and Exercise, 37, 881-903.

Букатин, А., Ю., Колузганов, В. М. (1986). Юный хоккеист. Москва: ФиС.

Быстров, В. А. (2000). Основы обучения и тренировки юных хоккеистов. Москва: Терра спорт.

Платонов, В. Н. (2004). Общчая теория подготовки спортсменов в олимпийском спорте. Киев: Олимпийская панорама. 


\title{
8-17 METŲ LEDO RITULININKŲ TECHNINIO RENGIMO OPTIMIZAVIMAS
}

\author{
Gracijus Girdauskas, Rimas Kazakevičius \\ Lietuvos sporto universitetas, Kaunas, Lietuva
}

\section{SANTRAUKA}

Tyrimo pagrindimas ir hipoteze. Sportininkų rengimo specialistai nustate orientacinius rengimo modelius, bet kartu iškèlè problemą dèl kartais neprognozuojamai kintamų modelių sąveikos (Hellard et al., 2006). Labai svarbu sportininkų rengimo programose numatyti ivvairiu rengimo rūšiu santykị. Dėl šios priežasties kai kurie tyrejjai rekomenduoja vertinti techninio rengimo programų galutinio rezultato (rungtynių) sąsajas (Bangsbo, 1994; Faigenbaum, Westcott, 2000). Neaptikta mokslo publikacijų, pagrindžiančių ledo ritulininkų daugiamečio rengimo atskirų etapų optimalių techninio rengimo modelių kurių pagrindu būtų galima sudaryti techninio parengtumo modelius. Hipotezé: manome, kad mūsų parengta ir eksperimentu patikrinta programa sudaro prielaidas optimizuoti kryptingą 8-17 metų ledo ritulininkų techninį rengima.

Tikslas - nustatyti 8-17 metų ledo ritulininkų techninio rengimo modelius.

Metodai. 2000-2010 m. buvo atliktas ilgalaikis vienos alternatyvos eksperimentas. Tiriamuju amžius - nuo 8 iki 18 metų. Buvo tirtos ivvairių techninio rengimo programų ir rezultatų sąsajos. Programos sudarytos atsižvelgiant i techniniam rengimui skirtą laiką, taikytas priemones ir užsienio specialistų rekomendacijas. Vèliau programas koregavome atsižvelgdami i gautus rezultatus. Naudojome šiuos testus: čiuožimo technikai ịvertinti - čiuožimą pirmyn ir atbulomis tiesiaja; specifiniams gebejjimams įvertinti (ritulio valdymo technikai) - manevrini čiuožimą varant rituli ir be jo.

Rezultatai buvo analizuojami naudojant matematinès statistikos metodus (aritmetini vidurki, jo nuokrypi, vidutinių reikšmių skirtumo reikšmingumas vertintas pagal Stjudento $t$ kriterijų $(\mathrm{n}=17)$. Tyrimas atliktas kiekvienu ledo ritulininkų rengimo laikotarpiu.

Rezultatai. Pradinio rengimo etapu (8-10 metu) didžiausias rezultatu prieaugio skirtumas pastebètas atliekant manevrinio čiuožimo rutulio varymo testą $(11,6 \%)$ ir čiuožiant atbulomis $(8,0 \%)$. Bazinio rengimo etapu didžiausias rezultatų prieaugio skirtumas pastebètas tiriamiesiems čiuožiant atbulomis $(7,0 \%)$ ir čiuožiant $30 \mathrm{~m}$ iš vietos $(6,3 \%)$. Specialiojo rengimo etapu didžiausias rezultatu prieaugio skirtumas aptiktas ledo ritulininkams čiuožiant atbulomis $(5,2 \%)$ ir čiuožiant $30 \mathrm{~m}$ iš vietos $(3,8 \%)$. Sportiniams rezultatams itakos turëjo paauglių organizmo vystymosi dèsningumai ir optimalus programos koregavimas atsižvelgiant ị pradinio ir bazinio rengimo etapų rezultatus.

Aptarimas ir išvados. 1. Ilgalaikiu eksperimentu nustatėme, kad sportininkų rengimo programos, parengtos atsižvelgiant į rekomendacijas, yra veiksmingos. 2. Didžiausi rezultatu prieaugiai pastebèti pirmu ir antru sportinio rengimo etapu. Manome, kad taip atsitinka dẻl ledo ritulio technikos biomechaninių judesių sudètingumo, o vèliau, juos patobulinus, rezultatų prieaugis sulèteja. 3. Laiko santykis, skiriamas techniniam rengimui pagal etapus (modeli), turètų vidutiniškai būti toks: I etapo - 55-53\%, II - 50-48\%, III - 47-44\%.

Raktažodžiai: techninis rengimas, manevrinis čiuožimas, eksperimentinė programa, rengimo optimizavimas, rengimo modelis.

Gauta 2013 m. kovo 5 d.

Received on March 5, 2013

Priimta $2013 \mathrm{~m}$. birželio $7 \mathrm{~d}$.

Accepted on June 7, 2013
Corresponding author Gracijus Girdauskas

Lithuanian Sports University

Sporto str. 6, LT-44221 Kaunas

Lithuania

Tel +370618 35220

E-mail gracijus.girdauskas@gmail.com 